\title{
STRUCTURE-ANTIBACTERIAL ACTIVITY RELATIONSHIP OF SOME AROMATIC ACIDS
}

\author{
D.T.U. ABEYTUNGA ${ }^{1 *}$; T.E.M. PEIRIS ${ }^{1}$ and R.L.C. WIJESUNDERA ${ }^{2}$ \\ 1 Department of Chemistry, University of Colombo, Colombo 3. \\ 2 Department of Botany, University of Colombo, Colombo 3.
}

(Received: 02 December 1997; accepted: 05 June 1998)

\begin{abstract}
Nine aromatic acids were tested for their antibacterial effect against Staphylococcus aureus. 3-phenylpropanoic acid was identified as the most active of the acids chosen for this bioassay. In general a 3,4-methylenedioxy substituent on the phenyl group reduces the activity against Staphylococcus aureus.
\end{abstract}

Keywords: Antibacterial action, aromatic acids, Staphylococcus aureus.

\section{INTRODUCTION}

Benzoic acid, the simplest aromatic acid is well known for its antimicrobial activity $^{1}$ and is widely used as a food preservative. Cinnamic acid derivatives have also been studied for possible antibacterial and antifungal activity. Ring substituted cinnamic acids ${ }^{2}$ (-methoxy, -amino, -chloro, -bromo, -hydroxy) have been tested against different bacteria and fungi and the halogenated derivatives have shown the highest activity against the tested organisms. trans-Ethyl pmethoxycinnamate ${ }^{3}$ is also known to inhibit in vitro, the growth of several fungi at $10-50 \mu \mathrm{g} / \mathrm{l}$. Geometry around the double bond is a key factor for the antifungal property of this compound, since the reduction of the double bond or conversion into the $c i s$-isomer by UV exposure resulted in total loss of anti-fungal activity.

The effect of piperine ${ }^{4}$ (the pyrrolidine amide of piperic acid) on the growth of microorganisms has been studied and the minimum inhibitory concentration required was greater than $100 \mu \mathrm{g} / \mathrm{ml}$ against all the tested organisms. Piperine, the principal alkaloid in pepper has been used in curing of meat by mankind for generations. The action of pepper on meat is scientifically explained as piperine inhibits the growth of fungi and bacteria. A recent study ${ }^{5}$ performed in our laboratory indicates that the piperic acid itself shows anti-bacterial activity against Staphylococcus aureus.

\section{METHODS AND MATERIALS}

The following two series of ten aromatic acids were chosen to conduct this study based on their structural relationship to benzoic, cinnamic and piperic acid which enabled us to find out the variation of antibacterial activity upon changing the length and saturation of the carbon chain attached to the phenyl ring. 


\section{Materials:}

Series 1:

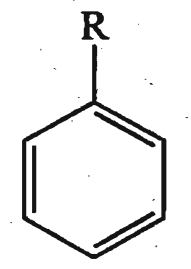

1

2

3

4

5
$-\mathrm{COOH}$

$-\mathrm{CH}=\mathrm{CH}-\mathrm{COOH}$

$-\mathrm{CH}_{2} \mathrm{CH}_{2} \mathrm{COOH}$

$-\mathrm{CH}=\mathrm{CH}-\mathrm{CH}=\mathrm{CH}-\mathrm{COOH}$

$-\mathrm{CH}_{2} \mathrm{CH}_{2} \mathrm{CH}_{2} \mathrm{CH}_{2} \mathrm{COOH}$
Benzoic acid

E-3-Phenylpropenoic acid/Cinnamic acid

3-Phenylpropanoic acid/Hydrocinnamic acid

5-Phenylpenta-2,4-dienoic acid

5-Phenylpentanoic acid/5-Penylvaleric acid

Series 2:

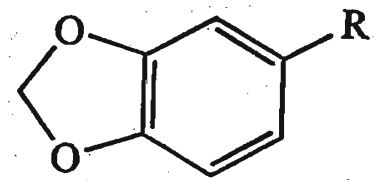

\begin{tabular}{|c|c|c|}
\hline 6 & $-\mathrm{COOH}$ & 3,4-Methylenedioxybenzoic acid/Piperonylic acic \\
\hline 7 & $-\mathrm{CH}=\mathrm{CH}-\mathrm{COOH}$ & E-3-(3,4-Methylenedioxyphenyl)propenoic acid \\
\hline 8 & $-\mathrm{CH}_{2} \mathrm{CH}_{2} \mathrm{COOH}$ & 3-(3,4-Methylenedioxyphenyl)propanoic acid \\
\hline$\underline{9}$ & $-\mathrm{CH}=\mathrm{CH}-\mathrm{CH}=\mathrm{CH}-\mathrm{COOH}$ & $\begin{array}{l}\text { E-5-(3,4-Methylenedioxyphenyl)penta-2,4- } \\
\text { dienoic acid/ Piperic acid }\end{array}$ \\
\hline 10 & $-\mathrm{CH}_{2} \mathrm{CH}_{2} \mathrm{CH}_{2} \mathrm{CH}_{2} \mathrm{COOH}$ & 5-(3,4-Methylenedioxyphenyl)pentanoic acid \\
\hline 11 &. $\mathrm{CHO}$ & Piperonal \\
\hline
\end{tabular}


Benzoic acid (1), cinnamic acid ( $\underline{\mathbf{2}})$ and piperic acid $(\underline{\mathbf{9}})$ were of BDH manufacture. Compound $\underline{\mathbf{3}}$ was obtained from $\underline{\mathbf{2}}$ and compound $\underline{\mathbf{5}}$ from $\underline{\mathbf{4}}$ by catalytic hydrogenation. Similar procedures were adopted in the preparation of compounds $\underline{8}$ from 7 and

10 from $\underline{9}$. Compound $\underline{4}$ was obtained from the reaction between cinnamaldehyde and malonic acid and compound $\mathbf{Z}$ was synthesized by a similar reaction of malonic acid with piperonal (11). Compound $\underline{\mathbf{6}}$ was obtained from the oxidation. of piperonal.

\section{Methods}

\section{Catalytic hydrogenation:}

The acid ( $3 \mathrm{mmol})$ was dissolved in methanol $(10 \mathrm{ml})$ and $10 \% \mathrm{Pd}$ on activated charcoal $(100 \mathrm{mg})$ was added to the reaction. The reaction flask was connected to a balloon filled with $\mathrm{H}_{2}$ through an adapter and the solution was stirred vigorously for $4 \mathrm{~h}$. The mixture was filtered to remove the catalyst and the solvent was concentrated to obtain the product.

\section{Condensation of malonic acid with piperonal:}

Piperonal (0.5g, $3.3 \mathrm{mmol})$ and malonic acid $(0.75 \mathrm{~g}, 7.2 \mathrm{mmol})$ were dissolved in pyridine $(1 \mathrm{ml})$ and a few drops of piperidine added. The mixture was refluxed for $1 \mathrm{~h}$, cooled to room temperature and poured into $5 \% \mathrm{HCl}(10 \mathrm{ml})$ while stirring. The precipitated product was filtered and washed with cold water. Recrystallization from methanol gave $\underline{\mathbf{7}}$.

Similar reaction of cinnamaldehyde with malonic acid gave compound $\underline{4}$ which was recrystallized from water.

\section{Oxidation of piperonal:}

A solution of $\mathrm{KMnO}_{4}(1.5 \mathrm{~g})$ in water $(30 \mathrm{ml})$ was added to piperonal ( $\left.1 \mathrm{~g}, 6.6 \mathrm{mmol}\right)$ in wate $\mathrm{r}(25 \mathrm{ml})$ in a $100 \mathrm{ml}$ flask while stirring on a steam bath at $70-80^{\circ} \mathrm{C}$ over $15 \mathrm{~min}$. Stirring and heating was continued for $1 / 2 \mathrm{~h}$ and the solution was made alkaline by adding $10 \% \mathrm{KOH}$. The mixture was filtered while hot and the $\mathrm{MnO}$, residue was washed with hot water. The filtrate was allowed to cool and acidified with conc. $\mathrm{HCl}$ until no further precipitate was formed. Recrystallization from ethanol gave $\underline{\mathbf{6}}$.

Compounds were identified by NMR spectroscopy of $\mathrm{CDCl}_{3}$ solutions on a 200 $\mathrm{MHz}$ Bruker spectrometer using tetramethylsilane (TMS) as the internal reference. 
Agar plate assay:

A drop of a $24 \mathrm{~h}$ old culture of the test bacterium Staphylococcus aureus in marmite peptone liquid medium was placed on a nutrient agar plate $(20 \mathrm{ml}$ nutrient agar in $9 \mathrm{~cm}$ petri dish) and spread over the surface using a glass spreader. Thereafter, the test solution $(5 \mathrm{ml}-25 \mathrm{ml}$ volumes from $10,000 \mathrm{ppm}$ solutions) was absorbed onto sterile filter paper discs of $6 \mathrm{~mm}$ diameter, and the discs placed on the innoculated agar plate. In the control, an equal volume of the solvent (ethyl acetate) was absorbed onto sterile filter paper disc. Each experiment was carried out in triplicate. The inoculated plates with the sterile filter paper discs were incubated for $48 \mathrm{~h}$ at $37^{\circ} \mathrm{C}$ and observed for inhibitory zones. The diameters of inhibitory zones were measured at the end of the incubation period.

\section{RESULTS}

Hydrocinnamic acid $\underline{\mathbf{3}}$ was obtained as a yellow oil from cinnamic acid in $92 \%$ yield.

'H NMR $\delta 10.20$ (s, broad), 7.33-7.18 (m, 5H, aromatic), 2.95 (t, 2H, $J=7.7$ $\mathrm{Hz}), 2.67(\mathrm{t}, 2 \mathrm{H}, J=7.7 \mathrm{~Hz}) ;{ }^{13} \mathrm{C}$ NMR $\delta 179.4,140.1,128.5,128.2,126.3,35.6,30.5$

5-Phenylpenta-2,4-dienoic acid $\underline{4}$ was obtained as an orange solid which recrystallized from water as yellow plates in $11 \%$ yield., m.p. $166-167^{\circ} \mathrm{C}$ ( $\mathrm{Lit}^{6}$. $\left.165-166^{\circ} \mathrm{C}\right){ }^{1} \mathrm{H}$ NMR $\delta 7.61-7.30(\mathrm{~m}, 6 \mathrm{H}), 6.93(\mathrm{~m}, 2 \mathrm{H}), 6.01(\mathrm{~d}, 1 \mathrm{H}, J=15.2) ;{ }^{13} \mathrm{C}$ NMR $\delta 171.8,146.9,141.6,135.8,129.3,128.8,127.3,125.9,120.1$

5-Phenylpentanoic acid $\underline{\mathbf{5}}$ was obtained as a yellow oil from acid $\underline{\mathbf{4}}$ in $8 \%$ yield. ' $\mathrm{H}$ NMR $\delta 8.20(\mathrm{~s}$, broad), 7.30-7.11 (m, 5H), $2.66(\mathrm{~m}, 2 \mathrm{H}), 2.39(\mathrm{~m}, 2 \mathrm{H}), 1.65(\mathrm{~m}$, $4 \mathrm{H}) ;{ }^{13} \mathrm{C}$ NMR $\delta 180.0,141.9,128.3,125.8,35.5,33.9,30.7,24.3$.

Piperonylic acid $\underline{6}$ was obtained as white needles in $9 \%$ yield. m.p. $228^{\circ} \mathrm{C}$ ( $\mathrm{Lit}^{\top} .229$ $\left.{ }^{\circ} \mathrm{C}\right){ }^{1} \mathrm{H}$ NMR $\delta 7.72(\mathrm{dd}, 1 \mathrm{H}, J=1.7$ and $8.2 \mathrm{~Hz}), 7.51(\mathrm{~d}, 1 \mathrm{H}, J=1.7 \mathrm{~Hz}), 6.87(\mathrm{~d}$, $1 \mathrm{H}, J=8.2 \mathrm{~Hz}), 6.08(\mathrm{~s}, 2 \mathrm{H}) ;{ }^{13} \mathrm{C}$ DEPT $-45 \delta 126.3,109.9,108.0,101.9$.

E-3-(3,4-Methylenedioxyphenyl)propenoic acid $\underline{\mathbf{Z}}$ was obtained as pale yellow needles in $69 \%$ yield. m.p. $258-260^{\circ} \mathrm{C}\left(\mathrm{Lit}^{6} .242^{\circ} \mathrm{C}\right){ }^{1} \mathrm{H}$ NMR $\delta 8.40(\mathrm{~s}, 1 \mathrm{H}), 7.66$ $(\mathrm{d}, 1 \mathrm{H}, J=16.1 \mathrm{~Hz}), 7.03(\mathrm{~d}, 1 \mathrm{H}, J=7.6 \mathrm{~Hz}), 6.84(\mathrm{~d}, 1 \mathrm{H}, J=7.6 \mathrm{~Hz}), 6.25(\mathrm{~d}, 1 \mathrm{H}$, $J=16.1 \mathrm{~Hz}), 6.02(\mathrm{~s}, 2 \mathrm{H}) .{ }^{13} \mathrm{C} \mathrm{NMR} \delta 169.3,149.5,148.2,145.0,128.6,124.3$, $115.9,108.4,106.4,101.4$.

3-(3,4-Methylenedioxyphenyl)propanoic acid $\underline{\mathbf{8}}$ was obtained from acid $\underline{\mathbf{7}}$ as pale yellow crystals in $75 \%$ yield. m.p., $77-78^{\circ} \mathrm{C}\left(\mathrm{Lit}^{6} .87-88^{\circ} \mathrm{C}\right){ }^{1} \mathrm{H}$ NMR $\delta 6.75-6.62$ (m, 3H, aromatic), $5.92(\mathrm{~s}, 2 \mathrm{H}), 2.87$ (broad $\mathrm{t}, 2 \mathrm{H}, J=7.4 \mathrm{~Hz}), 2.62(\mathrm{~m}, 2 \mathrm{H}) ;{ }^{13} \mathrm{C}$ NMR $\delta 179.1,147.6,146.0,133.9,121.1,108.7,108.3,100.8,35.9,30.3$. 
5-(3,4-Methylenedioxyphenyl)pentanoic acid 10 was obtained from piperic acid $\underline{9}$ as a brown solid in $98 \%$ yield, m.p. $95-96^{\circ} \mathrm{C}\left(\mathrm{Lit}^{6} .96^{\circ} \mathrm{C}\right){ }^{1} \mathrm{H}$ NMR $\delta 8.87(1 \mathrm{H}$, broad), 6.73-6.58 (m, 3H, aromatic), $5.90(\mathrm{~s}, 2 \mathrm{H}) 2.54$ (broad t, $2 \mathrm{H}, J=7.0 \mathrm{~Hz}$ ), $2.35($ broad t $, 2 \mathrm{H}, \mathrm{J}=7.0 \mathrm{~Hz}), 1.63(\mathrm{~m}, 4 \mathrm{H}) ;{ }^{13} \mathrm{C} \mathrm{NMR}\left(\mathrm{CDCl}_{3}\right) \delta 179.9,147.4,145.5$, $135.8,121.0,108.7,108.0,100.6,35.1,33.8,30.9,24.0$

\section{Antibacterial activity:}

Several compounds showed inhibitory activity against Staphylococcus aureus. The inhibitory activity of the aromatic acids in series 1 and series 2 , measured for different volumes of the acid solutions $(10,000 \mathrm{ppm})$ used in the bioassay are shown in Figure 1. Compound $\underline{7}$ was not soluble in ethyl acetate, hence the results are not comparable.
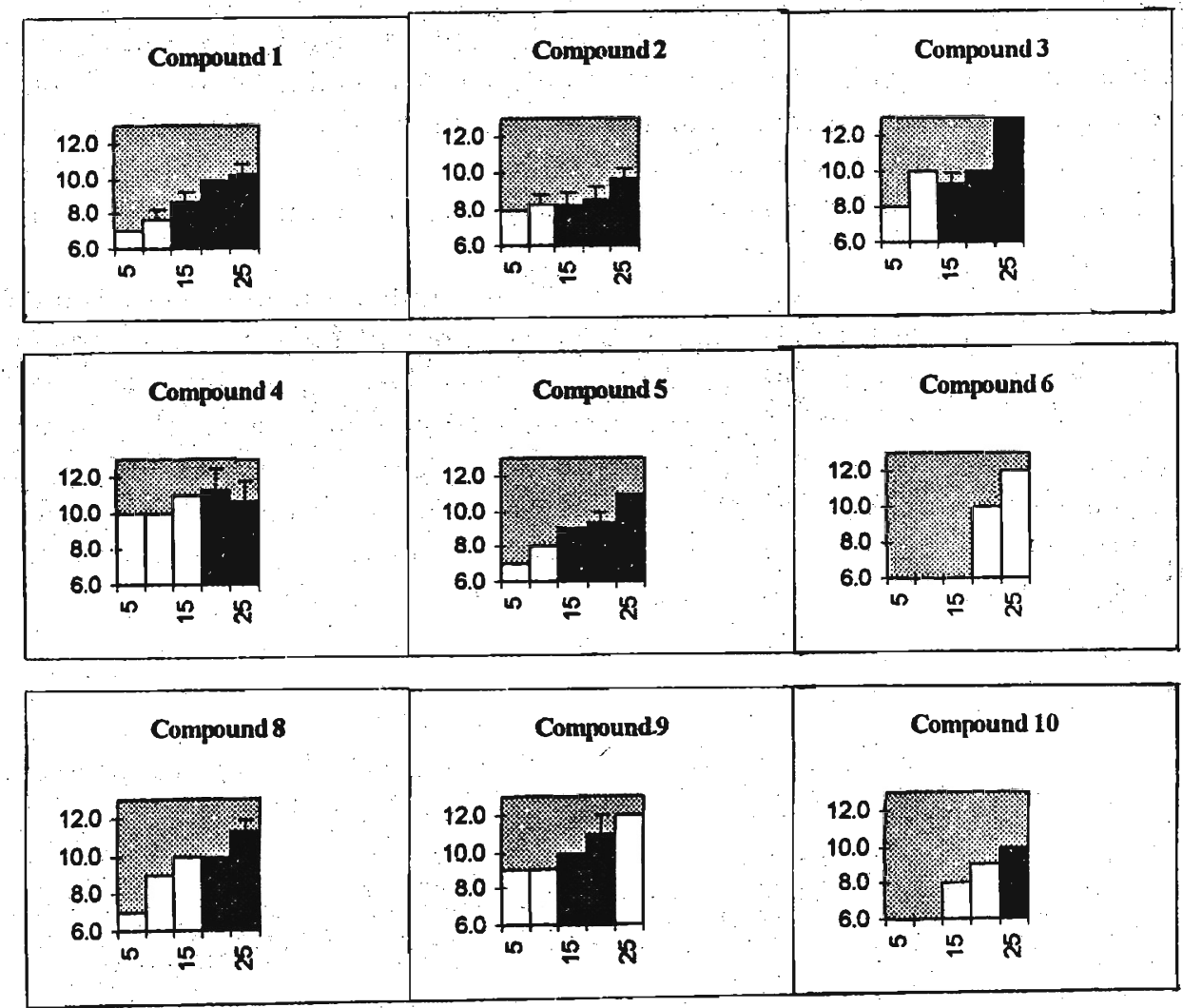

Figure 1: Diameter of inhibitory zone in $\mathrm{mm}(\mathrm{y}$ axis) against volume of test solution in $\mu l$.

Bars indicate standard deviation. Dark columns and white columns indicate very clearly demarcated inhibitory zones and less clearly demarcated inhibitory zones respectively. 


\section{DISCUSSION}

The spectroscopic data and comparisons with reported values confirm the formation of the required compounds in the Knoevenagel reaction, hydrogenation reactions and the $\mathrm{KMnO}_{4}$ oxidation.

Only the very clearly demarcated zones were taken as inhibitory in the interpretation of bio-assay results. Comparison of the antibacterial activity of the acids in the first series with the corresponding acids in the second series shows that the activity is diminished by the presence of a 3,4-methylenedioxy substituent on the phenyl ring. This is to be expected if the mechanisms of action of the acids are similar to the action of sulfonamides which act as a folic acid synthesis inhibitor. ${ }^{8}$ In contrast, comparison of activity of acid $\underline{4}$ and $\mathbf{q}$ shows a slight enhancement of activity in acid $\underline{\mathbf{9}}$ at $15 \mu \mathrm{llevel}$. However this enhancement is not observed at greater than $15 \mu l$ level.

Among the acids of the first series, hydrocinnamic acid $\underline{3}$ shows the highest antibacterial activity. Although hydrogenation of the double bond in compound $\underline{2}$ led to a marked enhancement of activity, similar hydrogenation of compound $\underline{4}$ had no significant effect on activity. In the second series, it was observed that hydrogenation of both double bonds in acid $\mathbf{9}$ decreased antibacterial activity.

Changes in antibacterial activity with the number of double bonds could be assessed by comparison of compound $\mathbf{2}$ with compound $\mathbf{4}$ in series 1 . Compound 4 seems to be a better candidate only if we consider the less clear inhibition zones in the interpretation. An increase in number of carbons attached to the aromatic nucleus appears to decrease activity as seen by comparing the results for the pairs of compounds $\mathbf{8} / \mathbf{2}$ and $\mathbf{8} / \mathbf{1 0}$. A plausible explanation for this behaviour is that the increase in hydrophobicity with increase in methylene groups affects the diffusion of these compounds on agar.

\section{References}

1. Desrosier N.W. \& Desrosier J.N.(1977). The Technology of food preservation. Fourth edition, CBS, New Delhi, India.

2. Ramanan P.N. \& Rao M.N.A. (1987). Antimicrobial activity of cinnamic acid derivatives. Indian Journal of Experimental Biology 25: 42-43.

3. Gupta S.K. \& Banerjee A.B. (1976). Lloydia 39: 218.

4. (a) Yamaguchi I. \& Ozeki S. (1985). Antibacterial and antitumor activities of Piperine from black pepper. Bull. Tokyo Kasei Daigaku 25: 201-203. (b) Sumathikutty M.A., Rajaraman K., Sankarikutty B., Narayanan 
C. S. \& Mathew A.G. (1981). Piperine. Lebensm.-Wiss. u. -Technol 14: 225228.

(c) Lee E.B., Shin K.H. \& Woo W.S., (1984). Pharmacological study on piperine. Arch. Pharm. Res 7(2): 127-132.

5. Wijayaratne D.T.U., Herath D., Wijesundera R.L.C. (1997). Antibacterial activity of piperine and its derivatives. Chemistry in Sri Lanka 14 (1):17.

6. Heilbron I. \& Bunbury H. M. (1953). Dictionary of organic compounds. Eyre \& spottiswoode, London, U.K.

7. The Merck Index. (1983). tenth edition, Merck \& co., Inc., N.J., USA.

8. Hammond S.M. \& Lambert P.A. (1981). Antibiotics and antimicrobial action. Edward Arnold, London, U.K. 